\title{
SBB Positive
}

National Cancer Institute

\section{Source}

National Cancer Institute. SBB Positive. NCI Thesaurus. Code C162100.

An indication that a sample has detectable Sudan black B staining. 